\title{
RESEPSI ALQURAN DALAM TRADISI PESANTREN DI INDONESIA (STUDI KAJIAN NAGHAM ALQURAN DI PONDOK PESANTREN TARBITAYUL QURAN NGADILUWEH KEDIRI)
}

\author{
'Ainatu Masrurin \\ UIN Sunan Kalijaga \\ Jalan Laksda Adisucipto, Caturtunggal, \\ Daerah Istimewa Yogyakarta 5528 \\ Email : ainamasrurin@gmail.com
}

\begin{abstract}
Abstrak
Nagham berarti bunyi kalimat dan keindahan suara ketika membaca Alquran. Dalam perkembangan Islam, pembacaan ayat suci Alquran dan penerimaan lantunan ayat suci Alquran merupakan bagian yang tidak tepisahkan dalam tradisi pesantren di Indonesia. Tidak terkecuali di Jawa, karena perkembangan nagham di pesantren Jawa satu sama lain saling berhubungan, dan salah satu tradisi pesantren dalam pembacaan ayat suci Alquran yaitu dengan nagham Mujawaad. Salah satu pesantren yang konsen dalam transmisi nagham Alquran yaitu pesantren Tarbitayul Quran Ngadilewuh Kediri dengan bentuk pengajaran klasik. Tujuan dari peneltian ini ialah mengetahui proses bagaimana proses transformasi penerimaan nagham di pesantren Trabitayul Quran. Metode yang digunakan dalam penelitian ini ialah deskriptif-experimental dengan melakukan pendekatan fenomenologi. Hasil dari penelitian ini menunjukkan bahwa pembacaan Alquran dengan nagham sebagaimana yang ada di PP. Tarbiyatul Qur'ān menunjukkan bahwa Alquran yang dibaca oleh Qari'dipengaruhi unsur internal dan eksternal. Untuk unsur ekternal meliputi perlombaan-perlombaan membaca Alquran (musabaqah) dan relasi social; sedangkan unsur internal yakni spiritual aesthetic meliputi puasa Dawud, do'a 'Ain Alquran, Mahabah Asma Nabi Yusuf dan Adam As, puasa 7 hari nyuprih suara Nabi Dawud As. Hal-hal demikian dilakukan sebagaimana bentuk usaha memperindah bacaan Alquran baik secara kapasitas diri maupun kaitanya dengan pengaruh orang yang mendengarkanya.
\end{abstract}

Keywords:

Lisan; Penerimaan Estetis; nagham al-Qur'ān; Pembacaan Mujawwad.

\begin{abstract}
Nagham means beautifully sound articulation of Qur'anic recitation. In the Islamic tradition, the practice and reception of nagham is part of pesantren tradition in Indonesia. In Java, the development of nagham in pesantren is interconnected to one another and one of the famous nagham in Qur'anic recitation is mujawwad. This research aims to examine the process of nagham reception in Pesantren Tarbitayul Quran, Ngadilewuh Kediri. This study utilizes phenomenology approach and experimental descriptive analysis. The result of this research shows that the reception of the Qori' of using specific and beatiful nagham is influenced by internal and external factors. In term of external factors, the qori frequently engage in Qur'anic recitation competitions and their interaction in social relations. For internal factors includes spiritual aesthetics: practicing Dawud's fasting, reciting do'a Qur'anic 'Ain, reciting do'a the affection of Nabi Yusuf and Adam, and many activities that consider beautifying their voices in Qur'anic recitation.
\end{abstract}

Keywords:

Oral tradition, Aesthetic Reception, nagham Alquran , Mujawwad Recitation.

\section{A. PENDAHULUAN}

Alquran sebagai teks agama mempunyai dimensi keterikatan terhadap segala bentuk aktivitas umat Muslim.1 Ia menyatu dalam ritual ibadah, terlibat dalam ucapan dan

1 Wilfred Cantwell Smith, Kitab Suci AgamaAgama, trans. Dedi Iswadi, vol. II (Bandung: Teraju, 2005), 115-44. 
Pondok Pesantren Tarbitayul Qur'an

Ngadiluweh Kediri)

bahkan menyatu dalam budaya dan adat masyarakat setempat. Hal ini senada dengan ungkapan Farid Esack yang menyatakan bahwa Alquran memenuhi berbagai fungsi dalam kehidupan kaum Muslim.2

Secara teoritis, fungsi tersebut menjelma menjadi sebuah resepsi.3Ia merujuk pada upaya kaum Muslim dalam menerima, merespon, memanfaatkan, atau menggunakan Alquran, baik sebagai teks yang memuat susunan sintaksis atau sebagai mushaf yang dibukukan dan memiliki makna tersendiri. Resepsi, sebagaimana diungkapkan Setiawan, terbagi ke dalam tiga bentuk. Pertama, resepsi kultural, yang mencoba mengungkap pengaruh dan peran Alquran dalam bentuk kultur dan budaya masyarakat. Kedua, resepsi hermeneutik, yang mengungkap perkembangan-perkembangan yang terkait dengan studi interpretasi teks dan aktivitas intrepretasi teks itu sendiri. Ketiga, resepsi estetik, yang mengungkap proses penerimaan dengan mata maupun telinga, pengalaman seni, serta cita rasa atas sebuah objek atau penampakan dari perwujudan bentuk resepsi estetik yang hanya dibaca untuk mendapatkan informasi di dalamnya, tetapi juga menghadirkan sisi keilahiannya sebagai teks bacaan yang diyakini bernilai ibadah, baik disertai pemahaman atau tidak.4

Secara historis, membaca adalah aktivitas interaksi kaum Muslim paling awal dengan Alquran, hingga sekarang. Salah satu aktifitas membaca Alquran yang menarik adalah ketika ia dibaca disertai bunyi nada dan irama. Seni membaca Alquran yang disertai dengan lagu atau langgam (nagham) merupakan salah satu bentuk kebudayaan Islam yang merepresentasikan bagaimana Alquran

${ }^{2}$ Farid Esack, The Qur'an: A Short Introduction (London: Oneworld Publication, 2002), 16.

${ }^{3}$ Ahmad Rafiq and Syahiron Syamsyudin, Sejarah Al-Qur'an: Dari Pewahyuan Dan Resepsi (Sebuah Pencarian Awal Metodologis) Islam Tradisi Dan Peradaban (Yogyakarta: SUKA-Press, 2012), 73-74.

${ }^{4}$ Khalil al-Qattan, Mabahits Fi Ulum Al-Qur'an (Riyadh: Mansyurat al-Asr al-Hadits, t.t, n.d.), 20-21. ditransformasikan dalam bentuk lisan melalui lagu. Sebagai bagian dari seni musik, seni baca Alquran bukan hanya bentuk suara dan bacaan yang indah, namun lebih dari itu, ia memiliki dimensi berupa lagu pokok dan variasi pengembangannya.5

Meskipun terdapat perbedaan pendapat tentang kapan dan siapa yang pertama kali melagukan Alquran, tetapi tidak menutup kemungkinan bahwa orang yang pertama kali menyenandungkan Alquran dengan irama yang indah adalah Nabi Muhammad sendiri. 'Abdullāh bin Mughaffāl pernah mengilustrasikan kemerduan suara Nabi ketika melantunkan surah al-Fath mampu membuat unta yang beliau tunggangi menjadi terperanjat. Selain itu, secara historis, lagu yang sampai sekarang populer digunakan untuk membaca Alquran di dunia Arab diduga salah satunya bersumber dari langgam para qiyan, perempuan yang melakukan pertunjukan menyanyi dan mendendangkan syair-syair pra-Islam dihadapan tamu-tamu.6

Langgam bacaan Alquran tersebut kemudian menyebar ke seluruh dunia Islam, termasuk Indonesia. Tetapi, terdapat jeda yang panjang dan kabur dalam sejarah penyebarannya di Indonesia. Studi awal menyebutkan bahwa langgam bacaan Alquran tersebut masuk ke Indonesia mulai tahun 1966 M, ketika pemerintah Mesir mengirim ahli pembaca Alquran (qari, jamaknya qurra') untuk tampil dari masjid ke masjid di beberapa daerah di Indonesia selama bulan Ramadan. Sejak tahun 1966 M hingga tahun

5 Syahiron Syamsyudin, Islam Tradisi Dan Peradaban,74-76 (Yogyakarta: SUKA-Press, 2012). Pertanyaan di atas merujuk pada uraian Ahmad Rafiq dalam 'Sejarah al-Qur'an: Dari Pewahyuan dan Resepsi (Sebuah Pencarian Awal Metodologis) yang menyebutkan beberapa contoh praktik resepsi di awal Islam dapat ditemukan dalam kitab-kitab hadist atau tafsir baca at-Tibyan fi Adab Hamalah al-Qur'an karya Imam al-Nawawi dan Fadail al-Qur'an karya Ibnu alDurais al-Farayabi, dan al-Nasa'i.

${ }^{6}$ Habib Hasan Toma, The Music of Arab (Amdeus Press, 2003), 3-6. 
Pondok Pesantren Tarbitayul Qura'n

Ngadiluweh Kediri)

1993 M ada banyak qurra' Timur Tengah yang datang ke Indonesia.7

Di Indonesia, sebelum 1966 M sudah berdiri Jamiyyah Qurra wal Huffadz (JQH) yakni pada $1950 \mathrm{M}$ yang dinaungi oleh organisasi keagamaan Nahdatul Ulama8, hal tersebut menunjukkan bahwa keberadaan pengembangan Alquran dibidang suara dan nagham sudah dirintis sejak dini. Kyai Yusuf Rahmat Dawud merupakan salah satu tokoh yang membantu cikal bakal berdirinya JQH di Indonesia. Kepiawaian dan keindahannya dalam membaca Alquran dengan nagham serta konsen pengembangan seni baca Alquran menjadikan beliau sebagai salah satu Qäri' rujukan di Jawa Timur, terbukti dengan diakuinya prestasi beliau di tingkat nasional dan internasional. Beliau juga ditunjuk sebagai salah satu dewan hakim MTQ tingkat nasional dalam bidang lagu.9

Pondok Pesantren Tarbiyatul Qur'an (PPTQ) Ngadiluweh Kediri (1973 M), merupakan pesantren rintisan yang beliau dirikan sebagai bentuk representatif pengembangan Alquran yang konsen dalam bidang nagham. Dengan ke-khas-annya, pesantren ini hanya mengadakan kegiatan belajar mengajar Alquran di bulan Ramadan dan Zulhijjah. Selain kegiatan belajar membaca Alquran dengan nagham, pesantren ini mengembangkan pembelajaran Tawasih, yakni pembelajaran syair yang berisi pujian kepada Nabi Muhammad, yang disebut Kristina Nelson sebagai jembatan antara resitasi Alquran dengan musik sekuler. Tawasih berfungsi sebagai langkah awal mengenal lagu pokok atau istilah lainya rumus

\footnotetext{
${ }^{7}$ Muhammad Yasser Arafat, Polemik Tilawah AlQur'an Langgam Jawa (IAIN Purwokerto, 2017).

${ }^{8}$ Muhammad Barir, Tradisi Al-Qur'an Di Pesisir: Jaringan Kiai Dalam Transmisi Tradisi Al-Qur an Di Generasi Islam Tanah Jawa (Yogyakarta: Nurmahera, 2017), 142-43.

${ }^{9}$ Dewi Masyitoh, putra bungsu KH. Yusuf Rahmat Dawud, "Wawancara" (Kediri, April 3, 2017).
}

utama untuk memindahkan lagu dalam rumus ke ayat-ayat Alquran.10

Pesantren Tarbiyatul Qur'an (PPTQ) dari awal berdiri hingga sekarang masih menggunakan tradisi klasikal dalam pengembangan nagham Alquran. Hal ini tergambar dari interaksi seorang guru dan murid saat berlangsung pengkajian Alquran.11 Namun hal tersebut mulai bergeser dari masa ke masa seiring kemajuan di bidang teknologi. Proses inilah yang kemudian menjadi modal seorang santri dalam mengkaji pembacaan Alquran dengan nagham, yakni dengan musafahah (menirukan apa yang dibawakan atau dilantunkan seorang guru). Maka muncul proses penerimaan (resepsi) terhadap ragam lagu, ritme, melodi yang membentuk komposisi tersendiri yang hampir mirip, sehingga ayat-ayat Alquran yang dibawakan dengan kapasitas kemampuan santri yang beragam menjadi sebuah bagian seni suara yang dinamis.

Berangkat dari fakta sejarah dan fenomena di Pesantren Tarbiyatul Qur'an Ngadiluweh Kediri, peneliti tertarik meneliti bagaimana

\footnotetext{
${ }^{10}$ Muhammad Barir, Tradisi Al-Qur an Di Pesisir: Jaringan Kiai Dalam Transmisi Tradisi Al-Qur'an Di Generasi Islam Tanah Jawa, 164-67. Tidak banyak ditemukan pesantren salaf di wilayah Jawa Timur yang konsen dalam pengembangan pembacaan al-Qur'an dengan nagam. Ditemukan beberapa yang masih mengkolaborasikan kajian kitab salaf dengan pengembangan nagam dalam membaca al-Qur`an dengan porsi terbatas seperti halnya pesantren Kranji Lamongan, Pesantren Nurul Qur'an al-Istiqomah (NQI) Bunga Gresik (KH. Saiful Munir yang merupakan pengasuh pesantren NQI merupakan murid langsung Kyai Yusuf Rahmat Dawud) dan Pesantren alMunawarah Gresik. Lihat Muhammad Barir, Muhammad Barir, Tradisi Al-Qur'an Di Pesisir: Jaringan Kiai Dalam Transmisi Tradisi Al-Qur an Di Generasi Islam Tanah Jawa.Muhammad Barir, Tradisi al-Qur an di Pesisir: Jaringan Kiai dalam Transmisi

11 "Berdasarkan Hasil Observasi," June 16, 2016. Selain kemajuan dan perkembangan teknologi proses itu terbantu dengan adanya alat perekam suara pada tahun 19-an hingga sampai tahun 2017-an proses pembelajaran mayoritas santri selain musafahah dengan seorang guru juga menggunakan media rekaman melalui smartphone.
} 

Indonesia (Studi Kajian Nagham Alquran Di Pondok Pesantren Tarbitayul Qur'an Ngadiluweh Kediri)

bentuk trasmisi-transformasi Alquran yang dilantunkan dengan nagham. Selain itu, peneliti mencoba melihat sisi penerimaan (resepsi) yang mengeksplorasi dimensi estetis dari seni Islam. Dengan memfokuskan pada bentuk penerimaan estetis dan prosesnya, penelitian ini lebih menonjolkan sisi keindahan dan penghayatan Alquran . Terlepas bahwa dari aspek estetik tersebut terdapat keinginan untuk membuat Alquran menjadi sebuah yang mudah dipahami.12

\section{B. HASIL DAN PEMBAHASAN}

\section{Nagham dalam Tradisi Kelisanan Alquran}

\section{a. Transmisi Alquran Secara Lisan}

Sebagai self-referential text $t^{13}$, Alquran menjelaskan banyak hal ini dalam kata قرأن dan kata قل sebagai representasi dimensi lisan. Di sisi lain, nama popular kitab suci ini dikenal dengan "Alquran" karena memang ia dibaca dengan lisan ${ }^{14}$ yang oleh Frederick M. Deny sebut sebagai kegunaan "Performatif" (The "Perfomative" Level of Quranic Use). Performatif di sini memusatkan aktivitasnya dalam ucapan dan pendengaran kata-kata suci Tuhan. Sedang kegunaan Informatif (The "Informatifve" Level of Qur'anic Use) ketika fokusnya pada aktivitas yang berhubungan dengan menggali pengetahuan atau informasi, seperti halnya tafsir, fiqih, aqidah, tarikh, dan sebagainya. ${ }^{15}$ Sebagaimana yang akan digali dalam kajian nagham Alquran penelitian ini.

Kondisi sosial budaya masyarakat Arab sebagai fakta sejarah juga menguatkan pula bahwa Alquran lahir dalam masyarakat Arab dengan budaya lisan yang sangat kuat. Bentuk kefasihan lidah merupakan satu dari tiga

\footnotetext{
12 Ahmad Baidowi, Resepsi Estetis Terhadap AlQur'an, vol. 8, 1 (Esensia, 2007), 20.

13 Nur Kholis Setiawan, Al-Qur'an Kitab Sastra Terbesar 92-94 (Yogyakarta: elSAQ Press, 2009).

${ }^{14}$ Alan Jones and Jane Dammen Mc Auliffe, Orality and Writing in Arabia Encyclopedia Of The Quran, vol. 3 (Leiden koln: Brill, 2001), 587-89. 17.

${ }^{15}$ Abul Haris Akbar, Musikalitas Al-Qur'an, n.d.,
}

keahlian manusia sempurna dalam masyarakat Arab sehingga sebuah peribahasa Arab mengatakan bahwa "kecantikan manusia adalah kefasihan lidahnya". ${ }^{16}$ Selain itu, secara umum ada empat budaya lisan dalam masyarakat Arab pra-Islam yakni syair atau puisi (syair), ramal (kāhin), orator (khätib), dan cerita-dongeng $(q \overline{a s})^{17}$

Penjelasan ini berusaha untuk menunjukkan bahwa kajian kelisanan Alquran adalah bagian dari upaya menyeimbangkan wacana yang terlampau didominasi oleh paradigma Alquran sebagai teks tertulis. Meskipun demikian, kelisanan dalam Alquran sungguh berbeda dengan teori dasar kelisanan (orality) yang sama sekali tidak berpengaruh dengan tulisan dan teks. ${ }^{18}$ Tradisi kelisanan Alquran memiliki tingkat luar biasa, sakral, dan teratur dalam hafalan di kehidupan muslim setiap hari. ${ }^{19}$ Senada dengan hal ini, lebih jauh Graham menuliskanya dalam sebuah artikel:" The only way to understand the Qur'an and its place in Muslim history and contemporary life is to grasp the centrality of its role as oral text par excellence" 20

Disebut sebagai kitab lisan, berarti Alquran erat kaitanya dengan aktivitas membaca dan mendengar. Untuk mendukung pendapat ini secara kebahasaan kata qur'ān sebagaimana pendapat kesarjanaan Muslim mempunyai banyak arti. ${ }^{21}$ Pertama, qur'ān merupakan kosa kata Arab bagi Taurat, kitab suci agama

16 Philip K. Hitti, Sejarah Ringkas Dunia Arab, trans.Ushuludin Hutagalung \&O.D.P Sihombing (Yogyakarta: Pustaka Iqra, 2001), 25-27.

17 Alan Jones and Jane Dammen Mc Auliffe, , "Orality and Writing in Arabia" (Ed), Encyclopedia Of The Quran, vol. 3 (Leiden koln: Brill, 2001), 587-588.

${ }^{18}$ Jane DAmmen Mc Auliffe, "Qur'an In Everyday Life” Encyclopedia Of Qur'an Vol. II , 80-86.

${ }^{19}$ Frederick Matheson Deny, Quran Recitation: A Traditional of Oral Performance and Transmission,1314., n.d.

${ }^{20}$ William A. Graham, Beyond The Written Wordm Oral Aspects of Scricture In The History of Religion, 585.

${ }^{21}$ M. Nur Kholis Setiawan, Al-Qur'ān Kitab Sastra Terbesar,.... , 57., n.d 

Indonesia (Studi Kajian Nagham Alquran Di Pondok Pesantren Tarbitayul Qura'n Ngadiluweh Kediri)

Yahudi, dan Injil, kitab suci evangelis. Kedua, Alquran sebagai infinitive berasal dari kata kerja qara'a yang berarti "mengumpulkan", "membacakan", atau"menyuarakan". Menurut Theodor Noldeke, kata qur'an bisa berarti membacakan dari sebuah teks atau membacakan secara langsung tanpa konsep atau mendiktekan pada seseorang yang menulis. Hal ini didasarkan pada ayat-ayat Q.S. 16:100, 17:95, 69:19, 73:20, 87:26.

Graham yang cederung mengartikan kata qur'an (verbal-noun dari akar kata ق-j-j) dengan "membaca memakai suara", Graham mendasarkan pernyataan bahwa bentuk penggunaan asli (originally) Alquran pada dua hal. $^{22}$ Pertama, dengan banyaknya pengulangan pada kata perintah (katakanlah!) yang mendahului lebih dari 300 kali bagian alam Alquran. Kedua, penggunaan kata تلى (to recite follow) yang berarti "membaca teks engan suara" yang tercatat sampai 63 kali. $^{23}$

\section{Nagham: Jembatan Transformasi Kelisanan Alquran}

\section{a. Sejarah Nagham dari Arab- Jawa}

Nagham berarti bunyi kalimat dan keindahan suara ketika membaca. ${ }^{24}$ Menurut ahli bahasa, nagham juga berarti bergetarnya sendi-sendi dengan keras yang menyebabkan tersentuhnya hati. ${ }^{25}$ Jika nagham diibaratkan sebuah proses maka keindahan adalah hasilnya, sedangkan objeknya dalam hal ini adalah Alquran. Nagham bisa disebut juga sebagai lagu atau melodi ${ }^{26}$ yang ber-ta'rif sebagai vokal suara indah tunggal tanpa diiringi alat musik, tidak terikat dengan not balok, dan hanya di gunakan untuk

22 Muhamma Fuad Abul Bāqi, Al-Mu'jam Al Mufaharas Li Alfä Al-Qur'ān (Beirut: ār al-Fikr, 1981), 571-75.

${ }^{23}$ Muhamma Fuad Abul Bāqi, 571-75.

24 Abi Husain Ahmad Faris, Mu'jam Maqāyis AlLugah (Dar al-Fikr, kairo), 452.

${ }^{25}$ Ibn Mandzur, , Lisan Al- 'Arab, (Daar al-Ma'arif, 1989), 4490. 64. memperindah bacaan Alquran. Ber-nagham berbeda dengan bermusik, yang dalam tradisi kebudayaan Islam oleh Isma'il R. al-Faruqi sebut handasah al-shaut (teknik suara). ${ }^{27}$

Nagham bersumber dari maqaimat al'Arabiyyah dalam tradisi kebudayaan bangsa Arab, yang kemudian berkembang lebih dari 200 buah jenis. Para Qári' di Indonesia menerjemahkan maqäm sebagai sistem melodi Arab. Dengan merujuk pada pengertian proses unik dalam pengembangan seni suara dan musik Arab yang selanjutnya berkembang di beberapa belahan dunia. ${ }^{28}$ Lebih sederhananya, Yaser menyatakan bahwa maqām diibaratkan sebagai sebuah sumur. Debit air sebagai nagham-nya, sedangkan teknik, variasi, warna dan gayanya merupakan cara yang ditempuh untuk memperoleh air tersebut. ${ }^{29}$ Namun para Qäri" utamanya di Indonesia sepakat dengan membatasi tujuh jenis nagham yang digunakan untuk melagukan Alquran,

Tidak banyak data yang ditemukan untuk menjangkau sisi historisitas pembacaan Alquran dengan lagu. Ada dua teori yang diusung oleh Ibnu Manzūr tentang asal-usul lagu Alquran. Pertama, lagu Alquran berasal dari nyanyian budak kafir yang tertawan ketika perang melawan kaum Muslimin dan pendapat kedua, menyatakan bahwa itu

27 Kristina Nelson, "Reciter and Listener: Some Factors Shaping The Mujawwad Style of Quranic Reciting," Ethnomusicology, University of Illion Press and Society of Ethnomusicology 26, no. 1 (January 1982): 41-47; Isma'il R. al-Faruqi and Lois Lamya alFaruqi, Atlas Budaya Islam $\square$ : Menjelajah Khazanah Peradaban Gemilan, trans. Ilyas Hasan (Bandung: Mizan, 2001), 491.

28 Habib Hasssan Touma, "The Maqam Phenomenon: An Improvisation Technique in Yhe Music of The Middle East" University of Illion Press and Society of Ethnomusicology 15, no. 1 (January 1971): 38-48.

${ }^{29}$ M. Yaser Arafat, "Tarekat Tilawatiyah: Melantunkan Al-Qur'an, Memakrifati Diri, Melakonkan Islam", Tesis Program Magister Antropologi Budaya Fakultas Ilmu Budaya Yogyakarta, 2013, (Universitas Gajah Yogyakarta, n.d.), 21. 

Indonesia (Studi Kajian Nagham Alquran Di Pondok Pesantren Tarbitayul Qur'an Ngadiluweh Kediri)

didapat dari nyanyian nenek moyang bangsa Arab, yang kemudian dipakai untuk melagukan Alquran.30 John Take atau W. S berasumsi bahwa lagu dan praktik melagukan Alquran diperoleh dari hasil jiplakan musik gereja yang digunakan oleh pendeta-pendeta Kristen Qibti. Namun, pendapat ini disangkal dengan maklumat Nabi Muhammad berikut ini

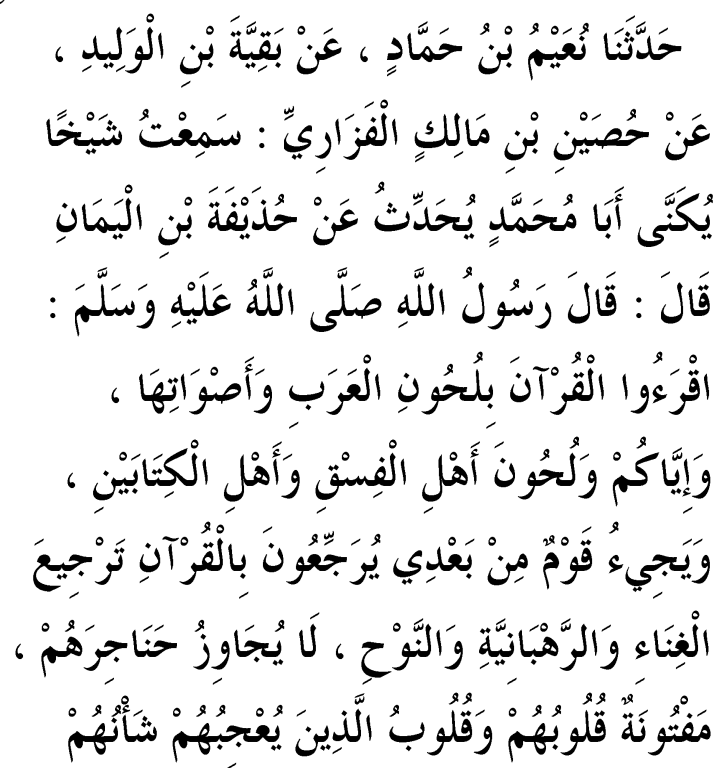

Ibnu Manzūr dalam kitab Lisān al-Aräb menginformasikan bahwa orang yang pertama membaca Alquran dengan lagu (alhan) adalah 'Ubaidullah bin Abi Bakrah yang kemudian diteruskan oleh 'Ubaidillah ibn Umar, dan selanjutnya Sa'ìd al-Allaf al-Ibādi. ${ }^{31}$ Ibn Qutaibah sebagaimana dipaparkan oleh Labib al-Sa'ìd memperinci dengan lebih detail mengenai hal ini. Beliau menyebutkan bahwa orang yang pertama kali membaca Alquran dengan lagu adalah Abdullāh bin Abi Bakrah. Bacaanya sedih (حزنا) -dengan suara lunak dan belum ada unsur lagu menyanyinya ( الغناء والحداء). Tradisi ini kemudian diwarisi oleh cucunya yang bernama 'Ubaidillāh bin Umar

\footnotetext{
${ }^{30}$ Ahmad Syahid "Sejarah dan Pengantar Ilmu Nagham: dalam buku Bunga Rampai Mutiara AlQur'an Pembinaan Qari' Qari' dan Hafidz Hafidzah, (Jak-sel: PP. Jam'iyyatul Qurra' wal Huffazh, 2006),2324.

${ }^{31}$ Ibnu Manzur Jamal ad-Din M. bin Mukarram alAnsary, Lisan Al-Arab Juz 19, (Dar Ihya' at-Turas alArabiyy, 630 H), 6506.
}

bin Abdullāh yang mempunyai murid bernama Sa'ìd al-'Allä́. Pada saat itu khalifah Härun ar-Räsyid terkesan dengan bacaannya, kemudian beliau memberi hadiah dan mengangkatnya sebagai seorang qäri'. Ada beberapa qāri' yang berasal dari suku Haisām, Aban, Ibn A'yun, dan lainya kemudian memaksukkan lagu-lagu dalam pembacaan tersebut. ${ }^{32}$

Pada selanjutnya, telah ditemukan rekaman pembacaan Alquran tertua yang berasal dari tahun 1885, yaitu bermula ketika Christian Snouck Hurgronje yang mengunjungi Makkah. Kemudia ia mengambil beberapa foto dan membuat rekaman Alquran dengan menggunakan alat inovasi terbaru Thomas Alva Edison yang disebut Waxclinders yang merekam bacaan surah al-Duha dalam versi murattal terlepas dari sedikitnya sumber sejarah yang dapat membuktikanya, pembacaan al-Qur'ān bi al-Mujawwad telah menemukan gaya tersendiri dalam melantunkan Alquran .

Di Indonesia gaya mujawwad berkembang pada permulaan ke 20. Aktor yang berperan dalam hal ini adalah para haji dan pelajarpelajar Indonesia yang telah menyelasaikan studi di Makkah dan kemudian pulang ke Indonesia. Lagu yang mereka bawa dikenal sebagai gaya Makkawi, sebuah penisbatan kepada tanah kelahiran lagu tersebut. Di antara qurra $\bar{a}$ yang masyhur dalam melagukan gaya ini adalah K.H. Arwani (Kudus), K.H. Sya'rani (Kudus), K.H. Munawwir (KrapyakYogyakarta), K.H. Abdul Qadir (KrapyakYogyakarta), K.H. Damanhuri (Malang-Jawa Timur), K.H. Ma'mun (Serang-Banten), K.H. Muntaha (Wonosobo), K.H. Azra'i Abdul Ra'uf (Medan). ${ }^{33}$

\footnotetext{
${ }^{32}$ Labib as-Said, Al-Jam'u as-Sauti Al-Awwal Li AlQur'an Al-Karim, n.d.

${ }^{33}$ Ahmad Syahid, Sejarah Dan Pengantar Ilmu Nagham Dalam Muhamaimin Zen Dan Akhmad Mustafid (Ed.). Bunga Rampai Mutiara Al-Qur'an Pembinaan Qari' Qari'ah Dan Hafidz Dan Hafidzah (Jak-sel: PP. Jami'iyyatul Qura' wal Huffadz, 2006), 28.
} 

Indonesia (Studi Kajian Nagham Alquran Di Pondok Pesantren Tarbitayul Qura'n Ngadiluweh Kediri)

Pada perkembangan selanjutnya, lagu Miṣry mulai dikenal oleh masyarakat Indonesia. Meskipun datang lebih belakang, tetapi gaya inilah yang kemudian mendominasi resitasi mujawwad dan lebih berkembang di Indonesia, Ini kisaran tahun 1973 ketika PTIQ (Perguruan Tinggi Ilmu Qur'ān) dan IIQ (Institut Ilmu Qur'ān) menjadikan lagu gaya Mișry sebagai acuan dalam mempelajari Alquran. Sampai-sampai mereka mendatangkan langsung dari Mesir, seperti Syekh 'Abdul Qādir Abdul Aẓim dan Syekh Sa'id al-Syarif. Pada waktu yang hampir bersamaan, gaya ini dijadikan sebagai lagu standar dalam lomba MTQ ( Musabaqah Tilawatil Qur'ān), baik tingkat nasional dan daerah. ${ }^{34}$ Di antara qurra' yang mahir dalam membawakan gaya ini adalah K.H. Bashori Alwi (Malang-Jawa Timur), K.H. Muhctar Luthfi (Jakarta), K.H A. Aziz Muslim (Tegal), K.H. Tb. Mansur Ma'mun (Serang-Banten), K.H. Muhammad Assiry (Jakarta), K.H. Ahmad Syahid (Bandung). ${ }^{35}$

Dalam peta yang lebih luas, gaya Mișry adalah yang paling banyak digunakan umat Islam di dunia. Berdasarkan data, ada kemungkinan dua factor yang melatar belakangi hal ini. Pertama, berbedaan mazhab yang dianut oleh kedua lagu itu berasal. Makkah adalah penganut mazhab Hanbali dan Maliki, yang mengklaim makruh pembacaan Alquran dengan lagu. Sedangkan Mesir, mayoritas masyarakat bermazhab Hanafi dan Syafi'i yang memperbolehkan praktik melagukan Alquran ${ }^{-36}$ Faktor inilah yang kemudian menumbuh kembangkan Mesir

34 Ahmad Syahid, Sejarah Dan Pengantar Ilmu Nagham Dalam Muhamaimin Zen Dan Akhmad Mustafid (Ed.). Bunga Rampai Mutiara Al-Qur'an Pembinaan Qari' Qari'ah Dan Hafidz Dan Hafidzah. (Jak-sel: PP. Jami'iyyatul Qura' wal Huffadz, 2006), 31 .

35 Ahmad Syahid, "Sejarah Dan Pengantar Ilmu Nagham” ......n.d., 30 .

${ }_{36}$ Muhsin Salim, Ilmu Nagham Al-Qur'an Dan Belajar Membaca Al-Qur'an Dengan Lagu (Metode SBA TEOTIK) (Jakarta: PT. Kebayoran Widya Ripta, 2004), 20-21. sebagai negeri gudangnya musisi dan qurra yang professional.

Faktor kedua adalah sosialisasi, sejak tahun 1960, pemerintah Mesir gencar mengirimkan Qurrä, andalan mereka ke Indonesia dan beberapa negara lainya untuk menyemarakkan bulan Ramadan. Di antara mereka yang pernah berkunjung ke Indonesia adalah Syekh 'Abd al-Bāsith Abd Samad, Syekh Tantawi, Syekh Maḥmūd Mujāhid, Syekh Muștafā Isma'il, Syekh 'Abd al-Hayyi Zahran, Syekh Maḥmūd Khālil al-Ḥusairi, Syekh 'Abd alQādir 'Abd al-Azịm. Qurra' inilah yang kemudian berkeliling mengunjungi masjidmasjid di seluruh Nusantara.

\section{b. Jenis Nagham Alquran}

Dalam etnomusikologi Arab, ada lebih 50 lagu (maqām) yang tidak hanya dipergunakan untuk mengalunkan ayat-ayat Alquran saja, tetapi juga syair-syair Arab yang masyhur. Dari sekian banyak lagu, ada tujuh lagu yang dianggap sebagai jendela lagu Alquran yang menjadi rumus atau master.yaitu bayāti, hijāaz, șabā, rāst, nahāwand, sikā, jihārkah. Setiap lagu tersebut mempunyai tausyikh atau tawasih (syair berisi pujian kepada Nabi), yang disebut Kristina Nelson sebagai jembatan antara resitasi Alquran dan musik sekuler. ${ }^{38}$ Tausyikh berguna sebagai langkah awal untuk mengenal lagu. Dengan tidak adanya keterikatan tajwid, membuat orang yang belajar dasar lebih mudah melakukan improvisasi.

\section{Praktik Pembacaan Alquran di PP. Tarbiyatul Qur'ān \\ a. Sejarah Berdirinya PP. Tarbiyatul Qur'an Ngadiluweh}

Perkembangan pesantren di wilayah kabupaten Kediri dan sekitarnya tidaklah terlepas dari pengaruh besar tokoh-tokoh Ulama', seperti KH. Chamim Djazuli (Ploso-

\footnotetext{
37 Ahmad Syahid, "Sejarah Dan Pengantar Ilmu Nagham" ...... 29-30., n.d.

${ }^{38}$ Kristina Nelson, The Art of Reciting The Qur'an, 101.
} 

Indonesia (Studi Kajian Nagham Alquran Di Pondok Pesantren Tarbitayul Qur'an Ngadiluweh Kediri)

Kediri), KH. Khabir (MangunsariTulungagung), KH. Abdul Jalil Mustaqim (PETA Kedungwaru-Tulungagung). Pada era setelahnya, muncul pesantren-pesantren yang merupakan hasil rintisan murid-murid tokoh Ulama di atas. Salah satunya adalah Pesantren Tarbiyatul Qur'ān. Pesantren ini terletak di Dusun Kendaldoyong Desa Banjarejo Kecamatan Ngadiluweh Kabupaten Kediri. Disebut Tarbiyatul Qur'ān karena memang nama tersebut merepresentasikan tujuan pendidikan dan pengembangan Alquran .

Berdasarkan hasil wawancara ${ }^{39}$ kepada keluarga pesantren Tarbiyatul Qur'ān, pesantren ini berdiri sejak tahun $1973 \mathrm{M}$. Pesantren ini didirikan sebagai sebuah pesantren yang mengikuti jejak profesionalisme dan pendidikan Alquran di bawah naungan Jam'iyyah Qurra'wal Huffaz. (Himpunan para seni dan penghafal Alquran ), yaitu organisasi para pencinta Alquran yang didirikan oleh KH. A. Wahid Hasyim pada tahun $1951 \mathrm{M}$, merupakan organisasi yang didirikan oleh Menteri Agama RI ke-III sebagai organisassi badan otonom di bawah naungan Nahḍatul 'Ulama'(NU). Pendiri sekaligus pengasuh pondok ini bernama Kiai H. Yusuf Rahmad bin Dawud, lahir di Palembang 24 Juni 1940, ayah beliau benama Gusti Dawoed dan ibunya RA. Zakiyah. Semasa kanak-kanak beliau belajar Alquran dan ilmu agama kepada kedua orang tuanya, kemudian beliau melanjutkan perjalanan menuntut ilmu ke Jawa Timur. Kyai H.Yusuf merupakan santri Hadratusyekh Hasyim As'ary (Tebuireng-Jombang), karena semasa remaja beliau menghabiskan waktu untuk belajar Alquran, Hadits, Fiqih, Akhlak dan ilmu-ilmu lainya di Tebuireng. Selanjutnya beliau juga belajar kepada menantu Hadratusyekh, Kyai H. Adlan Aly di Cukir, Diwek, Jombang. Disinilah beliau mulai menghafal Alquran .

\footnotetext{
39 Ita Purnama Putri KH. Yusuf Dawud, "Wawancara," February 11, 2018.
}

Rihlah keilmuan beliau berlanjut di wilayah Tulunggaung, beliau berguru kepada KH. Abdul Jalil Mustaqim Pondok Pesulukan Thoriqot Agung (PETA) di Kedungwaru, dan melanjutkan hafalan Alquran kepada $\mathrm{KH}$. Khabir Pondok Menara al-Fattah diMangunsari. Jarak antara Kedungwaru dan Mangunsari yang relatif dekat memungkinkan Kyai Yusuf menempuh disiplin keilmuan sekaligus, tariqat dan Alquran. Pada usia kurang lebih hampir 30 tahun beliau mengabdikan diri di ndalem KH. Chamim Djazuli (Gus Miek) yang merupakan pendiri Jami'iyyah Dzikrul Ghafilin. Semasa itu Kyai Yusuf membantu dan mengembangkan operasional kegiatan Jam'iyyah Dzikrul Ghafilin.

Selanjutnya, pernikahannya dengan Nyai Munifah Yahya Ghazali mengawali berdirinya Pesantren Tarbiyatul Qur'ān. Hadiah pernikahan berupa sebidang tanah di desa Banjarejo, Ngadiluweh merupakan amanah besar dari mertuanya, pasalnya wasiat untuk mendirikan sebuah pesantren di desa tersebut menuai tantangan yang cukup berat. Daerah Banjarejo dari dahulu terkenal sebagai daerah abangan dan menjadi pusat perjudian dan tempat mabuk-mabukan, sehingga adanya pesantren tersebut dapat dibilang sebagai penggangu. Sampai suatu ketika, kediaman Kyai H. Yusuf pernah dijarah dengan dibakarnya pekarangan peternakan secara gaib.

Kegiatan mengaji di Pesantren Tarbiyatul Qur'an pada era awal terpusat pada sosok Kyai H. Yusuf Dawud dan belum menggunakan guru atau tenaga lainya. Hingga akhirnya karena santri yang terus bertambah santri yang dulu merupakan murid-murid beliau diminta membantu untuk mengisi pembinaan dan pengajian Alquran. Tidak sebagaimana umumnya, pesantren ini hanya menyelenggarakan pembinaan dan pengajian Alquran dan kitab pada bulan-bulan tertentu seperti bulan Ramadan dan Zulhijjah.

Aktivitas pembacaan Alquran pada bulan Ramadlān ini terbagi dalam empat sesi, yaitu setelah subuh, setelah waktu dluha, setelah 
Pondok Pesantren Tarbitayul Qura'n

Ngadiluweh Kediri)

aṣhar, setelah Isya' atau tarawih. Dari keempat sesi tersebut kesemuanya fokus mempelajari pembacaan Alquran dengan nagham, dengan mendatangkan beberapa ustaz-ustazah, beberapa alumni yang sudah pernah menjuarai ajang MTQ baik di tingkat Regional, Nasional dan Internasional. Seperti KH. Saiful Munir (Qori'Internasional Turki), KH. Ghufron Nur Syam (Pembina LPTQ Kab. Kediri), Ustaz H. Zainal Arifin (Qori'terbaik pada MTQ Jawa Timur), Ustaz Agus Isna Hambali (Pembina JAMQUR Kab. Blitar), Ustaz H.Ahmad Khoirun Naim (Qori'terbaik pada MTQ Jawa Timur), Ustazah Dewi Masitoh (Qori'ah terbaik Remaja MTQ JQH Nasional).

Dalam rentang waktu 20 hari santri digembleng untuk mempelajari beberapa materi seputar Alquran meliputi tawasih/ tawsyeikh, tahqiq, tartil, tilawah, qira'ah sab'ah, dan pengajian kitab kuning. Tahqiq merupakan gaya membaca Alquran yang lebih menekankan pada ketepatan, cenderung pelan dan menonjolkan tajwidnya, karena itu ia menjadi satu-satunya gaya yang sering digunakan dalam pengajaran Alquran, selain itu tahqiq bukan gaya yang cocok untuk bacaan yang didengar publik dan bukan golongan dalam style of recitation. ${ }^{40}$

Sedangkan tartil dikenal sebagai gaya membaca Alquran yang paling awal, karena mempunyai nuansa yang sederhana, lugas, dan alamiah ia termasuk gaya yang sangat dianjurkan dalam membaca Alquran, ada yang mengatakan bahwa tahqiq itu adalah tartil tetapi pada kenyataanya kedua hal tersebut sangatlah berbeda. Gaya tartil dipopulerkan oleh Qari Mesir salah satunya adalah Syaikh al-Husairy, yang dibawakan dengan indah, jelas, tepat, dan mampu menghantarkan kehangatan resonasi bacaan. ${ }^{41}$ Gaya tilawah atau biasa disebut dengan mujawwad telah penulis jelaskan di bab

${ }^{40}$ Frederick Matheson Deny, "Quran Recitation: A Traditional of Oral Performance and Transmission," Jurnal Oral Tradition 4, no. 1-2 (1989): 19-20.

${ }^{41}$ Frederick Matheson Deny, 20. sebelumnya, dan yang dimaksud dengan pembelajaran qira'at sab'ah di pesantren ini adalah gaya bacaan yang digunakan adalah mujawwad dengan teks qira'at sab'ah.

Adapun metode yang digunakan setiap pengajar seluruhnya hampir mirip, yakni musafahah melihat dan menirukan. Saat guru memberi contoh satu ayat dengan lagu tertentu, santri mendengarkan kemudian diulang bersama-sama, dan setiap santri mencoba satu persatu dan guru memberikan koreksi benar/salah, kritik dan saran atas bacaan yang dibawakan si santri. Di akhir setiap pengajian ada salah satu santri perwakilan dari putra dan putri untuk membawakan maqra' yang diajarkan dari awal hingga akhir secara menyeluruh. Satu buah maqra' yang diajarkan oleh seorang guru paling singkat memakan waktu satu hari, dan yang lama 2-3 hari. Kemudain di akhir seluruh rangkaian, diadakan MTQ antar santri, tujuanya adalah sebagai bahan evaluasi selama 20 hari mengikuti kegiatan tersebut.

Puncak kegiatan pengajian Alquran nya yaitu pada malam 21 Ramadlān sekaligus dalam rangka memperingati Nuzul Alquran, dalam acara ini biasanya juga diadakan lailatul qira' $a h^{42}$ untuk para guru, alumni, dan qäri'-qäri'ah yang hadir. Dan dilanjutkan dengan acara pengajian sekaligus pengumuman kejuaraan. Ketika KH. Yusuf masih hidup, setiap pengajian Alquran setelah subuh beliau sering memberikan ijazah ${ }^{43}$ pagi santri mukim. Baik itu berupa amalan-amalan

\footnotetext{
${ }^{42}$ Pembcaan al-Qur'ān dengan nagam yang dibaca oleh qāri'- qāri'ah sepanajang malam baik sendiri atauapun duet, dengan model buka baca spontanitas, di daerah lain di Indonesia seperti Jawa Barat, Jawa Tengah dan DIY hal seperti ini disebut dengan haflah tilawwah al-Qur'an yang mana para Qari' dan Qri'ah tampil secara live di hadapkan langsung para pendengarnya agar dapat langsung mendengar respon dan komentar mereka, yang demikian ini dianggap penting karena sebagai bentuk apresiasi dan inspirasi untuk meningkatkan skill.

${ }^{43}$ Sejenis amalan khusus yang bisa dilakukan apabila sudah ada ijab qabul antara guru dan murid yang sanad keilmuanya hingga Rasulullah
} 

Indonesia (Studi Kajian Nagham Alquran Di Pondok Pesantren Tarbitayul Qur'an Ngadiluweh Kediri)

sebagai tirakat menjaga kejernihan suara ataupun penguat hafalan.

Pada bulan Dzulhijjah pembacaan Alquran di pesantren ini relative lebih singkat, hanya 5 hari ustaz-ustazahpun yang didatangkan tidak sebanyak ketika bulan Ramadlān, seperti ustaz Aminudin (JQH Kab, Jombang), Ust. Ali Bustomi SQ, (Qäri' terbaik Nasional pada MTQN), ustazah Dewi Masyitoh (Qäri'ah terbaik JQHN). Maqra' yang dipelajari dalam setiap pengajian al-Qur'āpun lebih bervariatif, ada seperti al-Nisā' ayat 1-4, al-Rum 21-22, al-Furqān 74 yang secara khsus dibaca pada acara walimatul 'urs, atau Ali Imran 144-147, 159, al-Ahzab 21 yang khusus dibaca ketika peringatan Maulid Nabi Muhammad SAW, Ali Imran 133-135 yang dibaca secara khusus pada acara halal bi ḥalal, atau al-Isra' 1-3, alNajm 1-5 pada peringatan Isra' Mi'raj Nabi Muhammad SAW. Dan masih banyak lagi lainya.

Pada bulan Dzuhijjah 2017 lalu, salah seorang ustaz mengajarkan maqra'alNisa'103-106, maqra' ini tidak secara khusus dibacakan sebagaimana maqra'-maqra' yang telah disebutkan di atas, maqra' ini bersifat umum bisa dibawakan ketika acara apapun baik formal ataupun non-formal. Pada proses pengajaran lagunyapun ustaz tidak sekedar mengajarkan untuk menirukan, kadangkala juga memberi pemahaman tafsir atas ayat-ayat tersebut, sekaligus mengajarkan nama lagu jenis, dan maqam nya, untuk santri pemula hal yang paling ditekankan adalah menirukan, mengulangi, dan mengingatnya. Sedang untuk santri senior pengembangan lagu dan variasi lebih ditekankan pada masing-masing individu.

UstazB:

“Asslamu'a'laikum

Warahmatullahi Wabaraktuh, teman-teman santriwan-santriwati yang saya banggakan marilah sebelum kita mulai majlis tilawah Alquran ini dengan bacaan surat al-Fātihah mudah-mudahhan kegiatan ini berjalan lancar. Langsung saja mari kita buka surat al-Nisa': 103: A'udzubillahi minnassyaithanirrajīm...... tirukan bersama satu dua tiga"
Santri“'A'udzubillahiminnasyaithanirrajīm ..... ’UstadzB: "Bismillahirrahmanirrahim.. dicoba satu, dua tiga..."Santri "Bismillahirrahmanirrahim..."

Ustadz B: "Faidzā qadaitumussholāta fadzkurullaha qiyamā.. mari dicoba satu dua tiga..."

Santri "Faidzā qadaitumussholata fadzkurullaha qiyama-."

Ustadz B: "Fadzkurullaha qiyāma waqu'üdan wa 'ala junubikum.."

Santri

"Fadzkurullaha qiyama waqu'udan wa 'ala junubikum.."

Ustadz B: "Faidzatma'nantum faaqīmus shalaaah"

Santri

"Faidzatma'nantum faaqimus shalaaah". Dst.

Lagu-lagu yang diadopsi dalam QS. alNisa' 103-106 ini berasal dari tawasih/tawsyekh yang sudah dijelaskan di bab sebelumnya, gambaran lagu besarnya adalah tawasih, ${ }^{44}$ namun ketika sudah masuk dalam sebuah ayat, melodi dan variasi pada tawasih telah mengalami perubahan sebagaimana kemampuan seorang Qäri' menghasilkan variasi. Dalam jangka waktu kurang lebih dua hari materi QS. al-Nisa'103106 diajarkan, untuk mempermudah dalam memorization melody mereka merakam dalam bentuk audio baik menggunakan hp atau alat perekam lainya. Lama waktu bacaan maqra' QS. al-Nisā' $103-106$ berkisar 5 menit ketika dibaca secara mujawwad dan 2,5 menit ketika dibaca tartil. dam dalam satu maqra' QS. al-Nisā' $103-106$ terdapat lima jenis lagu, yang dimulai dengan nada bayati, nahawand, räst, dan sikah.

\section{b. Ekpresi Estetis Pembacaan Alquran di PP. Tarbiyatul Qur'ān dengan Nagham}

Ilmu Tajwid dikenal memberikan panduan mengenai bagaimana seharusnya setiap huruf dilafalkan. Tajwid tidak mengatur masalah

\footnotetext{
${ }^{44}$ Anna K. Rasmussen, Women the Recited Qur'an, and Islamic Music in Indonesia, .....100-101., n.d.
} 

Indonesia (Studi Kajian Nagham Alquran Di Pondok Pesantren Tarbitayul Qura'n Ngadiluweh Kediri)

tempo, irama, atau intonasi dalam pembacaan Alquran. Alhasil, tidak banyak aspek yang dapat didokumetasikan pada masa pramodern, dengan dalih bahwa tidak ada petunjuk dalam beberapa riwayat dari Nabi tentang pemasukkan melodi dalam membaca Alquran sebagai bagian utama dalam Alquran. Anna M. Gade dalam penelitianya mengungkapkan bahwa ditemukan pada periode Bani Abbasiyah para qurra' melantunkan Alquran, hal tersebut diduga sebagai hasil kreativitas manusia yang mengawinkan gaya bermusik Arab dan Persia, pendapat lain menyebutkan bahwa menggunakan lagu atau mempelajarinya bukan bagian penting dalam membaca Alquran dengan menganggap bahwa lagu tersebut hanya diperbolehkan secara hukum. ${ }^{45}$

Sebagai bentuk kreativitas manusiawi, nagham atau gaya bermusik mengilhami umat Islam untuk mendekati Alquran secara indah, walaupun banyak menuai perdebatan di kalangan para ulama'salaf, ${ }^{46}$

Secara tradisi, umat Islam mendekati Alquran dari dua sudut pandang yang berbeda, tetapi masih saling terkait, yaitu, Alquran yang ditafsiri dan Alquran yang dibaca. Yang pertama, umat Islam mendedikasikan pikiran terbaik mereka, dan yang terkahir mereka mencurahkan suara dan talenta musiknya. Selama ilmu tafsir bertujuan untuk menyingkap makna yang tersirat dari teks, dan seni baca Alquran sebagai alat utama untuk menyebarkanya

Pernyataan kedua di atas menjadi poin penting dalam penelitian ini, jika tafsir sebagai sebuah jalan mengungkap makna yang tersirat dari dalam Alquran, tilawah melengkapinya melalui seni nada dan musik.

45 Anna M.Gade, Perfection Make Practice: Learning, Emotion and Recited Qur'an in Indonesia (Honolulu: University of Hawai Press, 2004), 181.

${ }^{46}$ KASYAF (Khazanah Santri Salaf), Trilogi Musik: Nuansa Musik Dalam Konstruksi Fikih Tradisi Tasawuf Dan Relevansi Dakwah (Kediri, Lirboyo Press, 2017), 172-73; Kristina Nelson, The Art Of Reciting The Qur'an, 2001, 32.
Tilawah Alquran sebagai perantara penyebaran diterima secara berbeda oleh seluruh umat Islam di dunia. Tidak akan sama karakter bacaan umat Muslim Indonesia dengan Muslim di Afrika dalam mengekpresikan kesenian Alquran .

Lebih spesifik, penelitian ini mencoba menggali sisi kedua yang digunakan dalam mendekati Alquran. Aktivitas tilawah Alquran pada komunitas Pondok Pesantren Tarbiyatul Qur'ān Kediri akan dilihat melalui pendekatan fenomenologi. Fenomenolgi berusaha memandang perilaku manusia sebagai sesuatu yang bermakna, karena telah jelas bahwa makna tersebut lahir dari kesadaran manusia akan perilakunya, makna tersebut bisa jadi bersifat individu maupun social kolektif. Perilaku keagamaan merupakan hasil manifestasi perilaku kolekstif social sebuah komunitas, sebagaimna dikatakan oleh Heddy Shri Ahimsa bahwa pandangan, pengetahuan, nilai, norma, dan aturan dalam individu dibangun melalui perilaku kolektivitas. ${ }^{47}$ Alquran adalah bagian dari pedoman dan perangkat sebuah komunitas (umat Islam) menjalankan agamanya. Dari sisi definisi, secara fenomenologis agama didefinisikan sebagai sebuah kesadaran mengenai dunia yang berlawanan (empiris dan gaib), dan bagaimana manusia saling berhubungan secara simbolik maupun tidak dengan kedua dunia tersebut. ${ }^{48}$

Berkaitan dengan hal tersebut Husserl sebagaimana dikutip oleh Ahimsa juga menjelaskan bahwa tujuan agama didekati dengan fenomenologi adalah berusaha mendeskripsikan dengan baik gejala yang ada di luar diri manusia sebagaimana gejala yang nyata ditampilkan secara sadar. ${ }^{49}$ Hasil deskripsi tersebut kemudia menjadi tolak ukur

47 Heddy Shri Ahimsa-Putra, "Fenomenologi Agama: Pendekatan Fenomenologi Untuk Memahami Agama” Jurnal Walisongo 20, no. 2 (November 2012): 281-285.

${ }^{48}$ Heddy Shri Ahimsa-Putra, 294.

${ }^{49}$ Heddy Shri Ahimsa-Putra, 284. 
Pondok Pesantren Tarbitayul Qur'an

Ngadiluweh Kediri)

common sense masyarakat memahami hal terkait.

Berdasarkan hal tersebut, penulis akan mendeskripsikan bentuk-bentuk ekspresi ustadz, santri, qari' dan qari'ah PPTQ dalam berinteraksi dengan Alquran sebagai berikut:

Quranic Competition (Musabaqah Tilawatil Qur'an)

Kegiatan MTQ merupakan bagian dari tradisi Alquran yang telah melembaga di kalangan masyarakat Indonesia, sebelumnya MTQ lahir dari lembaga JQH NU pada tahun 1952 yang diketuai oleh Abu Bakar Atjeh, yang mampu mengakomodir kurang lebih 50 qurra' di seluruh Indonesia. Secara resmi untuk pertama kalinya, MTQ digelar pada 1968 di Makassar Sulawesi Selatan, ${ }^{50}$ dan kemudian sampai saat ini kegiatan ini secara rutin dilaksanakan oleh LPTQ (Lembaga Pengembangan Tilawatil Qur'ān) di seluruh tingkatan baik Desa, Kecamatan, Kabupaten, Provinsi, Nasional, bahkan Internasional.

Kegiatan serupa juga dilaksanakan di Pondok Pesantren Tarbiatul Qur'an Kediri secara turun temurun sebagai bentuk apresiasi dan evalusi pada santri mukim bulan Ramadlān, MTQ di gelar dengan beberapa cabang dan kategori sebagaimana telah dijelaskan di bab sebelumnya. Ada hal yang berbeda dari MTQ pada umumnya, jika biasanya MTQ hanya berhak diikuti oleh seorang qari'-qari'ah professional dan teruji, di PPTQ semua santri baik pemula, menengah dan senior wajib mengikuti, hal ini sempat dikeluhkan oleh beberapa santri pemula.

Namun di sisi lain kegiatan MTQ ini mampu menyedot perhatian beberapa santri yang pada akhirnya mempelajari Tilawah Alquran secara serius. Sebagaimana pernyataan dari salah seorang santri berikut:

ya mau gimana lagi, karena sifatnya wajib mau tidak mau saya harus ikut dan belajar. Meskipun saya masih pemula

\footnotetext{
${ }^{50}$ Muhammad Barir, Tradisi Al-Qur'an Di Pesisir: Jaringan Kiai Dalam Transmisi Tradisi Al-Qur an Di Generasi Islam Tanah Jawa, 86-87.
}

semoga sedikit banyak lomba ini menjadi bagian dari cambuk untuk terus berlatih dan berlatih ${ }^{51}$

Pernyataan tersebut mengindikasikan bahwa MTQ sejak lama dijadikan sebagai tolak ukur qura dalam memberikan pengaruh terhadap perkembangan kualitasnya. Dengan menghadirkan beberapa aturan khusus, secara umum tidak jauh dari apa yang telah diajarkan di pondok tersebut. Selain itu ada standarisasi bacaan dan lagu yang digunakan untuk menilai, meliputi : ${ }^{52}$

\begin{tabular}{|ll|ll|}
\hline a) & $\begin{array}{l}\text { Suara (kehalusan, } \\
\text { kelembutan, } \\
\text { kekuatan/ power) }\end{array}$ & $\begin{array}{l}\text { e) Irama, gaya, dan } \\
\text { variasi }\end{array}$ & \\
\hline b) & Jumlah lagu & f) Pengaturan nafas \\
\hline c) & Lagu pertama dan & $\begin{array}{l}\text { g) Adab dan } \\
\text { fashahah } h^{53}\end{array}$ & \\
& penutup & h) Makharij al-huruf \\
d) & $\begin{array}{l}\text { Peralihan } \\
\text { keutuhan tempo }\end{array}$ & dan Tajwid \\
\hline
\end{tabular}

Kejuaraan dalam MTQ ditentukan oleh dewan hakim atau juri yang sudah berpengalaman dibidangnya. Aturan dan ukuran tersebut sebagaimana telah dirumuskan oleh LPTQ. Dengan paling sedikit kesalahan, merakalah yang dinobatkan sebagai juara. Kelebihan di bidang lagu dan variasi menjadi point penting dalam mengolah bacaan. Hal tersebut didukung oleh faktor ketrampilan masing-masing qurra'. Penobatan menjadi juara bagi qurra' melekat tidak hanya saat setelah usai perlombaan. Sebagaimana dituturkan oleh Ust. Bastomi bahwa menjadi juara sama halnya mengemban tanggung jawab untuk senantiasa mengamalkan,

\footnotetext{
51 Mbak Yeyen, "Wawancara Salah Satu Santri Mukim Bulan Ramadlan," n.d.

${ }^{52}$ Anne K. Rasmussen, Woman, the Recited Qur'an, and Islamic Music in Indonesia , (USA: University of California Press, 2010), 134.

${ }^{53}$ Penilaian fashohah meliputi waqaf dan ibtida' saat seorang Qari'membaca al-Qur'ān
} 
Pondok Pesantren Tarbitayul Qura'n

Ngadiluweh Kediri)

mengajarkan kemampunnya kepada orang lain. $^{54}$

Pada pengajian bulan Dzulhijjah beliau juga sempat memberikan nasihat berupa do'a ketika akan mengikuti musābaqah, sebagaimana pernyataan berikut:

Ya Allah duh gusti, jika dengan menangnya saya dalam perlombaan ini menjadikan saya sombong dan jauh dari-Mu, maka jangan berikan, namun jika dengan menangnya saya dalam perlombaan ini saya menjadi lebih giat membaca Alquran dan dekat dengan-Mu maka berikanlah ${ }^{55}$

Mereka qurra' yang telah pernah dinobatkan menjadi juara akan sering diundang untuk mengisi haflah tilawah Alquran, lailatul qira'ah, maupun mengaji pada acara-acara tertentu. Masyarakat pada umumnya turut serta mengapresiasi qurra' melalui acara-acara yang bersifat publik, upaya-upaya inilah yang kemudian dinilai sebagai hasil ekspansi pembacaan Alquran dikenal masyarakat dengan begitu eksis.Dengan kemajuan teknologi, adanya internet memudahkan qurra' saat ini eksis di dunia maya, ditemukan banyak qurra' di Indonesia terkenal dan menuai banyak pujian di akun media sosial mereka. Channel YouTube, Instagram, dan Facebook menjadi plafform yang memegang rekor paling sering digunakan untuk mengupload dan share penampilan mereka, baik secara live atau rekaman vidio mereka. Sebagaimana Darwis Hasibuan, Mastia Lestaluhu, Zainudin, Syamsuri, Salam Jiharka, Wardah Hasan yang

\footnotetext{
${ }^{54}$ Ust. Bastomi telah beberapa kali menjuarai ajang MTQ di tingkat Provinsi dan Nasional, Tahun 2000 menjadi juara harapan pada MTQN cabang remaja, tahun 2009 sampai 2016 beturut-turut juara 1 pada cabang Qiraah Sab'ah di DIY, dan Juara 2 tingkat Nasional pada cabang Qiraat Sab'ah tahun 2010 di Banten. Wawancara dengan Ust. Bastomi 30 Agustus 2017.

${ }^{55}$ Nasihat ust. Bastomi kepada qurra' yang akan mengikuti musābā qah saat pengajian bulan Dzuhijjah Agustus 2017.
}

baru setahun ini terhimpun dalam akun dan channel "Sang Qori"”.

Selain itu, qurra' di PPTQ dan umumnya, menguatkan jaringan mereka melalui grupgrup Whatsapp. Di PPTQ terdapat grup Alumni dan Santri PPTQ Kediri. Sedang di beberapa grup WA pada umumnya penulis menemukan grup seperti Qurra'Indonesia, Qurra' Yogyakarta, Qurra'Jawa Tengah dll. Grup-grup ini dimanfaatkan sebagai ajang sharing, tukar pengalaman dan saling koreksi bagi sesama qurra' dengan saling voice note membacakan Alquran dengan nagham.

Hal -hal di atas secara massif telah menjadi tradisi pembacaan Alquran yang berkembang di Indonesia saat ini, bahwa mengaji, belajar tilawah Alquran tidak harus dilakukan secara langsung/ musafahah dengan guru, tapi bisa menggunakan akun media sosial secara online. Hal tersebut sedikit berbeda dengan apa yang ada di PPTQ, bahwa pertemuan antara guru dan murid menjadi bagian penting transfer ilmu yang dianggap sebagai sebuah hal yang sakral.

\section{c. Spiritual Aesthetic (Estetika Kebatinan)}

Ekpresi MTQ merupakan bagian ekternal seorang qurra' berinteraksi dengan Alquran yakni melalui kompetisi. Di PPTQ selain latihan sebagai ikhiyar fisik, sisi rohani menjadi perhatian untuk dilatih dan dikembangkan. Ketika KH. Yusuf Dawud masih hidup santri yang mukim pada bulan Ramadlān dan Dzulhijjah selalu mendapatkan amalan-amalan khusus untuk meningkatkan, menghaluskan, melenturkan kualitas batin mereka agar saat membaca Alquran dengan nagham tidak sekedar indah namun juga disertai kekhusyu'an bahkan mampu membawa audien yang mendengarkanya hanyut dan tenggelam dalam bacaan tersebut.

Penelitian yang sama yang membahas tentang kebatinan di bidang tilawah sudah pernah dibahas oleh Yasser Arafat dalam tesisnya yang berjudul Tarekat Tilawatiyah. Tesis ini menjelaskan bahwa lagu/ nagham dalam tilawah dinisbatkan dengan lagu-lagu Jawa seperti sekar macapat, kemudian 

Indonesia (Studi Kajian Nagham Alquran Di Pondok Pesantren Tarbitayul Qur'an Ngadiluweh Kediri)

ditafsirkan secara rinci dengan pernyataan bahwa nada-nada tersebut menjelaskan lelaku urip (jalan hidup) manusia, mulai dari awal penciptaan, hingga kematian. ${ }^{56}$

Namun hal tersebut berbeda dengan yang ada di PPTQ Kediri, santri yang menekuni dunia per-tilāwahan setidaknya dan dianjurkan menjalankan beberpa tirakatan atau amalan untuk mencapai kondisi batin yang berkualitas berikut ini:

\section{1) Puasa Dawud}

Sebagaimana ijazah dari KH. Yusuf, puasa Dawud dilakukan minimal satu tahun, dengan amalan membaca QS. Saba'ayat 10-11 berikut sebagai wirid, dilakukan setiap setelah selesai mengerjakan sholat fadlu sebanyak tujuh kali.

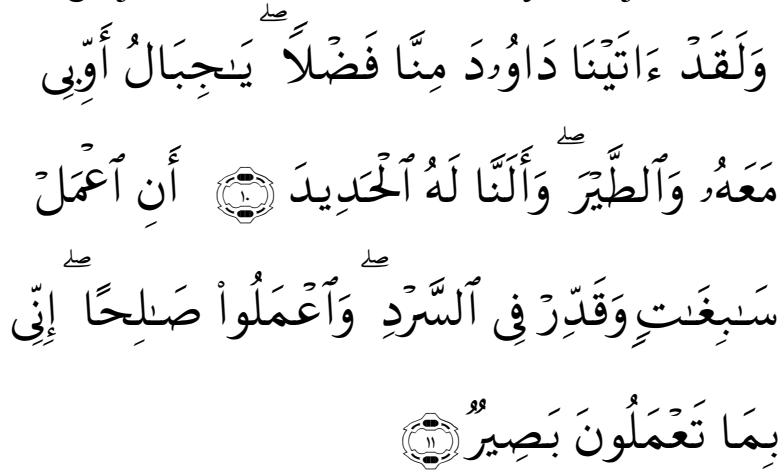

\section{2) Puasa 7 Hari}

Puasa 7 hari ini ditujukan untuk "nyuprih" (mencari) suara nabi Dawud As. Sebagaimana dikenal dalam sejarah bahwa beliau adalah Nabi yang mempunyai keindahan suara sebagai mukjizatnya. Selain di siang hari puasa, pada malam hari dianjurkan melaksanakan sholat tahajud dan hajat kemudia membaca faithạh di air yang sumurnya masih alami (mengandung zat asam arang) dengan mengambil satu timba,

${ }^{56}$ Muhammad Yasser Arafat, Berta'aruf Dengan Tilawah Langgam Jawa, Makalah Diskusi Public “ Polemik Tilawah Al-Qur'an Langgam Jawa” Di IAIN Purwokerto, Jawa Tengah Pada Tanggal 21 Februari 2017.; Muhammad Yasser Arafat, "Tarekat Tilawatiyah: Melantunkan Al-Qur'an, Memakrifati Diri, Melakonkan" (program Magister Antropologi Budaya Fakultas Ilmu Budaya Universitas Gajah Mada, 2013), 161-67. dibacakan faithah dan melakukan istinsyak ${ }^{57}$ sebanyak tiga kali, kemudia sisa airnya di minum dan digunakan untuk mencuci muka. Sambil istinsyak membaca do'a:

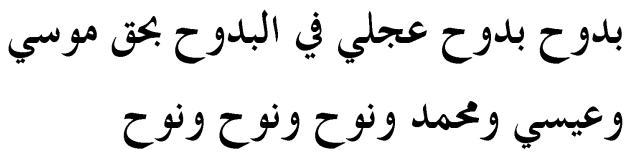

Dan do'a berikut:

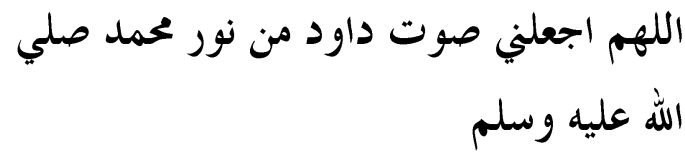

Adapun air yang digunakan istinsyak sebelumnya dibacakan al-Fatihah dengan tawāsul kepada:

\begin{tabular}{|l|l|}
\hline $\begin{array}{l}\text { 1. Nabi Muhammad } \\
\text { SAW }\end{array}$ & 6. Nabi Musa As \\
\hline 2. Nabi Dawud As & 7. Nabi Isa As \\
\hline 3. Nabi Yusuf As & 8. Nabi Nuh AS \\
\hline 4. Nabi Khidir As & 9. Waliyullah \\
\hline 5. Nabi Sulaiman As & $\begin{array}{l}\text { 10. Guru-guru Alquran } \\
\text { dan kedua orang tua }\end{array}$ \\
\hline
\end{tabular}

Tabel 2. Tawasul yang ditujukan

\section{3) Do'a 'Ain Alquran}

$$
\begin{aligned}
& \text { اللهم اغفرلي بما يقولون ولاتؤخذبي عمّا يقولون } \\
& \text { واجعلني خيرا مُّا يظّّون }
\end{aligned}
$$

Do'a ini dibaca setiap akan membaca Alquran dihadapan orang banyak maupun sendiri, baik itu ketika ajang permlombaan, atau acara tertentu. Tujuannya sederhana supaya terpelihara dari rasa ujub, riya' (pamer), sum'ah dalam membaca Alquran. Dan supaya mencegah terkena ain-nya Alquran.

\section{4) Mahabah Asma Nabi Yusuf dan Adam}

\footnotetext{
${ }^{57}$ Menghirup air melalui hidung kemudian dikelurakan, sebagaimana yang dilakukan pada sunnah wudlu
} 
Resepsi Alquran Dalam Tradisi Pesantren Di Indonesia (Studi Kajian Nagham Alquran Di Pondok Pesantren Tarbitayul Qura'n Ngadiluweh Kediri)

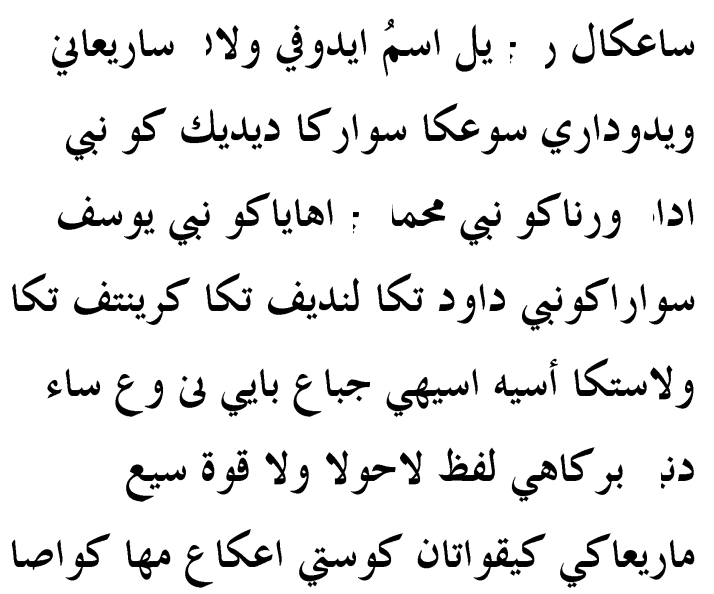

"Sangkal rucil ismu idupe wulan, saringane widodari songko suwargo dedegku Nabi Adam (sambil memukulkan kaki kanan ke bumi sebanyak tiga kali), wernaku Nabi Muhammad, cahayaku Nabi Yusuf, suaraku Nabi Daawud teka landhep tela krentep teka welas asih asihe jabang bayine wong sak ndunyi, berkahe lafadz lahaula walaa quwwata sing maringake kekuatan gusti ingkang maha kuoso"

Disertai Tawāsul membaca al-Fatihạ ditujukan kepada:

1. Nabi Muhammad

2. Nabi Adam As

3. Nabi Daud As

4. Nabi Yusuf As

5. Guru-guru Alquran

6. Kedua orangtua

Ini dikerjakan di dini hari setelah mengumandangkan azan kemudian membaca asma tersebut. Tujuanya sebenarnya tidak jauh beda dengan amalan-alaman sebelumnya, yakni menjaga dan meminta dianugerahi suara agar jernih, halus, dan kuat. Beberapa hal tentang asumsi-asumsi dan bentuk pengalaman qurra' berinteraksi dengan Alquran juga dikuatkan dengan pernyataan berikut ini:

"Membaca Alquran jadi semakin semangat dan greget" "Biar betah membaca Alquran kalau memebacanya dengan lagu"“Tambah khusyu' karena diiringi lagu yang indah",58

Dari pernyataan di atas dapat disimpulkan bahwa penggunaan lagu/nagham dalam membaca Alquran menjadi sesuatu hal yang penting dengan tujuan untuk meningkatkan kulaitas bacaan dan dalam rangka mendekatkan dirikepada Allah. Seperti halnya muncul pengalaman batiniyah yang mampu dirasakan oleh qurra'. Pengalaman batiniyah ini biasa dikenal dengan zauq, Dalam dunia sufi zauq juga disebut dengan wajd, sebagaimana dituturkan oleh Abi al- Qāsim al-Qusyairi mendefinisikan bahwa wajd merupakan suatu hal yang hadir dalam hati seorang secara alamiah tanpa kesengajaan dan usaha, Imam al-Ghāzalȳ menjelaskan juga bahwa wajd adalah sebuah ungkapan atas suatu kondisi hati seseorang yang terjadi dari hasil sama, ${ }^{59}$ Untuk memperolehnya ada dua cara, pertama wajd (ekstase) yang datang secara alamiah, seorang tidak perlu menghadirkanya melalui sama' ataupun prosesi lainya, bahkan ketika seseorang sama sekali tidak menginginkanya, wajd seperti ini disebut dengan wajd hajim (ekstase alamiah). Kedua, wajd berwujud dengan bantuan usaha (takalluf) dengan sengaja dan disebut dengan tawajud. Kondisi ini berarti berusaha menghadirkan wajd dalam hati. ${ }^{60}$ Hal serupa pernah dikemukakan oleh Imam al-GhāzalI pernah disampaikan oleh Nabi SAW.

Dalam membaca al-Qur'a, terdapat tata cara, ketentuan, dan etika, dan tawajud termasuk salah satu sikap yang telah ditentukan sebagaimana Hadist tersebut. Nabi SAW memerintahkan orang ketika membaca Alquran harus dengan khusyu' dan diiringi dengan tangis, jika ia tidak mampu menangis, dianjurkan untuk berpura-pura untuk dirinya

\footnotetext{
58 Nisaul, "Wawancara Dengan Santri Mukim," September 4, 2017.

${ }^{59}$ KASYAF (Khazanah Santri Salaf), Trilogi Musik: Nuansa Musik Dalam Konstruksi Fikih Tradisi Tasawuf Dan Relevansi Dakwah, 213.

${ }^{60}$ KASYAF (Khazanah Santri Salaf), 215-217.
} 

Indonesia (Studi Kajian Nagham Alquran Di Pondok Pesantren Tarbitayul Qur'an Ngadiluweh Kediri)

sendiri. Dan hendaknya membaca Alquran memang harus penuh dengan penghayatan sampai dapat mengeluarkan air mata.

Sebagai contoh seorang kaligrafer mencurahkan wajd melalui karya sedang seorang qurra' mencurahkanya melalui bacaan dengan nadanya. Inayath Khan pernah mengatakan bahwa music/lagu adalah puncak dari sebuah kata-kata, musik dijadikan perantara komunikasi antar jiwa dengan jiwa, kemudian meresapinya ke dalam diri. Melalui lagu inilah seorang Qäri' mengkomunikan bacaan dengan jiwanya.

\section{The Public Relation (Hubungan masyarakat)}

Dalam komunitas muslim tradisional perayaan hari-hari besar Islam seperti Maulid Nabi, Isra'Mi'raj, perayaan awal bulan Rajab, Nuzulul Alquran dianggap kurang sempurna tanpa kehadiran bacaan Alquran , ${ }^{61}$ dengan gaya yang digunakan adalah mujawwad. Hal serupa juga disampaikan oleh Mahmood Ayoub bahwa pembacaan Alquran, dalam satu majelis merupakan suatu keberkahan. ${ }^{62}$

Pembacaan Alquran dalam mengawali sebuah kegiatan, baik acara peringatan seperti hari Islam, telah menjadi ritual yang massif di kalangan masyarakat Indonesia. Tidak hanya itu, acara-acara resmi di kalangan kampus, perkantoran, LSM, dan komunitas dan intansi pemerintahan lainya juga memulainya dengan bacaan Alquran. Mereka menganggap bahwa acara yang diawali dengan pembacaan Alquran mempunyai keberkahan yang lebih.

Melihat fakta tersebut, bahwa qurra' mempunyai andil menonjol dalam masyarakat. Bacaan Alquran di ruang publik telah menjadi bagian tak terpisahkan dari aktivitas

61 Ingrid Mattson, Ulumul Qur'an Zaman Kita: Pengantar Untuk Memahami Konteks, Kisah, Dan Sejarah Al-Qur'an (Jakarta: Penerbit Zaman, 2013), 163.

${ }^{62}$ Mahmoud Ayoub, "The Qur'an in Muslim Life and Practice," Mei 2018, https://iis.ac.uk/quran-muslimlife-and-practice. masyarakat. ${ }^{63}$ Hal yang sama juga dirasakan oleh Ust. Bastomi, beliau bercerita sebagaimana pernyataan berikut:

"Selama bulan Ramadlān saya selalu menjadi Imam Tarawwih salah satu Masjid Agung di wilayah Kalimantan, selain menjadi Imam saya juga diamanahi mengisi kajian-kajian selama bulan Ramadlān di masjid tersebut" ${ }^{44}$

$\begin{array}{ccr}\text { Pernyataan } & \text { tersebut } & \text { setidaknya } \\ \text { mengindikasikan } & \text { bahwa } & \text { seorang }\end{array}$ Qari'memgang oeran dalam mengakomodir aktivitas peribadatan, karena asumsi masyarakat secara umum akan lebih tertarik beribadah di Masjid jika seirang Imam yang dihadirkan selain fasih dalam bacaan Alquran juga indah dalam melagukanya.

\section{SIMPULAN}

Dari diskusi panjang seputar nagham Alquran baik dalam kajian sejarah dan bentuk resepsi yang telah dilakukan di PP. Tarbiyatul Qur'ān Ngadiluweh Kediri, maka dapat disimpulkan bahwa Ulama-ulama di Tanah Jawa mempunyai andil besar dalam pengembangan dan penyerbarluasan nagham di Nusantara yang diadopsi dari Qurra' Timur Tengah sebagaimana yang dikenal saat ini, dan dalam pembacaan Alquran dengan nagham sebagaimana yang ada di PP. Tarbiyatul Qur'ān menunjukkan bahwa Alquran yang dibaca oleh Qari' dipengaruhi unsur internal dan eksternal, unsur ekternal meliputi quranic competition dan pubic relation, sedangkan unsur internal yakni spiritual aesthetic meliputi puasa Dawud, do'a 'Ain Alquran, Mahabah Asma Nabi Yusuf dan Adam As, puasa 7 hari nyuprih suara Nabi Dawud As. Hal-hal demikian dilakukan sebagaimana bentuk usaha memperindah bacaan Alquran baik secara kapasitas diri maupun kaitanya dengan pengaruh orang yang mendengarkanya.

63 Anna K. Rasmussen, The Qur'àn in Indonesia Daily Life: The Public of Musical Oratory, vol. 45, 1 (Winter: Ethnomusicology, 2001).

${ }^{64}$ Ust. Bastomi, "Wawancara." 

Indonesia (Studi Kajian Nagham Alquran Di Pondok Pesantren Tarbitayul Qura'n Ngadiluweh Kediri)

\section{DAFTAR PUSTAKA}

Abi Husain Ahmad Faris. Mu'jam Maqāyis Al-Lugah. Dar al-Fikr, kairo.

Abul Haris Akbar. Musikalitas Al-Qur'ān, n.d. Ahmad Baidowi. Resepsi Estetis Terhadap AlQur'an. Vol. 8. 1. Esensia, 2007.

Ahmad Rafiq, and Syahiron Syamsyudin. Sejarah Al-Qur'an: Dari Pewahyuan Dan Resepsi (Sebuah Pencarian Awal Metodologis) Islam Tradisi Dan Peradaban. Yogyakarta: SUKA-Press, 2012.

Ahmad Syahid. Sejarah Dan Pengantar Ilmu Nagham, n.d.

- Sejarah Dan Pengantar Ilmu Nagham Dalam Muhamaimin Zen Dan Akhmad Mustafid (Ed.). Bunga Rampai Mutiara AlQur'an Pembinaan Qari' Qari'ah Dan Hafidz Dan Hafidzah. Jak-sel: PP. Jami'iyyatul Qura' wal Huffadz, 2006.

Alan Jones, and Jane Dammen Mc Auliffe. Orality and Writing in Arabia Encyclopedia Of The Quran. Vol. 3. Leiden koln: Brill, 2001.

Almifda. "Wawancara Santri Mukim," September 4, 2017.

Anna K. Rasmussen. The Qur'an in Indonesia Daily Life: The Public of Musical Oratory. Vol. 45. 1. Winter: Ethnomusicology, 2001. - Women the Recited Qur'an, and Islamic Music in Indonesia, ....100-101., n.d.

Anna M.Gade. Perfection Make Practice: Learning, Emotion and Recited Qur'an in Indonesia. Honolulu: University of Hawai Press, 2004.

Anne K. Rasmussen. Woman, the Recited Qur'an, and Islamic Music in Indonesia. USA: University of California Press, 2010.

"Berdasarkan Hasil Observasi," June 16, 2016. Dewi Masyitoh, putra bungsu KH. Yusuf Rahmat Dawud. "Wawancara." Kediri, April 3, 2017.

Farid Esack. The Qur'an: A Short Introduction. London: Oneworld
Publication, 2002.

Frederick Matheson Deny. "Quran Recitation: A Traditional of Oral Performance and Transmission." Jurnal Oral Tradition 4, no. 1-2 (1989).

- Quran Recitation: A Traditional of Oral Performance and Transmission,1314., n.d.

Habib Hasan Toma. The Music of Arab. Amdeus Press, 2003.

Habib Hasssan Touma. "The Maqam Phenomenon: An Improvisation Technique in Yhe Music of The Middle East." University of Illion Press and Society of Ethnomusicology 15, no. 1 (January 1971).

Heddy Shri Ahimsa-Putra. "Fenomenologi Agama: Pendekatan Fenomenologi Untuk Memahami Agama." Jurnal Walisongo 20, no. 2 (November 2012).

Ibn Mandzur. Lisan Al-'Arab. Daar alMa'arif, 1989.

Ibnu Manzur Jamal ad-Din M. bin Mukarram al-Ansary. Lisan Al-Arab Juz 19. Dar Ihya' at-Turas al-Arabiyy, 630.

Ingrid Mattson. Ulumul Qur'an Zaman Kita: Pengantar Untuk Memahami Konteks, Kisah, Dan Sejarah Al-Qur'an. Jakarta: Penerbit Zaman, 2013.

Isma'il R. al-Faruqi, and Lois Lamya alFaruqi. Atlas Budaya Islam $\square$ : Menjelajah Khazanah Peradaban Gemilan. Translated by Ilyas Hasan. Bandung: Mizan, 2001.

Ita Purnama Putri KH. Yusuf Dawud. "Wawancara," February 11, 2018.

Jane DAmmen Mc Auliffe. Qur'an In Everyday Life, Encyclopedia Of Qur'an. Vol. 2, n.d.

KASYAF (Khazanah Santri Salaf). Trilogi Musik: Nuansa Musik Dalam Konstruksi Fikih Tradisi Tasawuf Dan Relevansi Dakwah. Kediri: Lirboyo Press, 2017.

Khalil al-Qattan. Mabahits Fi Ulum AlQur'an. Riyadh: Mansyurat al-Asr alHadits, t.t, n.d.

Kristina Nelson. "Reciter and Listener: Some Factors Shaping The Mujawwad Style of Quranic Reciting." Ethnomusicology, University of Illion Press and Society of 

Indonesia (Studi Kajian Nagham Alquran Di Pondok Pesantren Tarbitayul Qur'an Ngadiluweh Kediri)

Ethnomusicology 26, no. 1 (January 1982): 41-47.

. The Art of Reciting The Qur'an. New York: University of Texas Press, 2001.

- The Art Of Reciting The Qur'an. New York: The America University Press, 2001.

Labib as-Said. Al-Jam'u as-Sauti Al-Awwal Li Al-Qur'an Al-Karim, n.d.

M. Nur Kholis Setiawan. Al-Qur'an Kitab Sastra Terbesar, n.d.

M. Yaser Arafat. "Tarekat Tilawatiyah: Melantunkan Al-Qur'an, Memakrifati Diri, Melakonkan Islam', Tesis Program Magister Antropologi Budaya Fakultas Ilmu Budaya Yogyakarta, 2013, 21." Universitas Gajah Yogyakarta, n.d.

Mahmoud Ayoub. "The Qur'an in Muslim Life and Practice," Mei 2018. https://iis.ac.uk/quran-muslim-life-andpractice.

- The Qur'an Recited. Vol. 27. 2. Middle East Studies Association Bulletin, 1993.

Mbak Yeyen. "Wawancara Salah Satu Santri Mukim Bulan Ramadlan," n.d.

Muhamma Fuad Abul Bāqi. Al-Mu'jam Al Mufaharas Li Alfäz Al-Qur'ān. Beirut: ār al-Fikr, 1981.

Muhammad Barir. Tradisi Al-Qur'an Di Pesisir: Jaringan Kiai Dalam Transmisi Tradisi Al-Qur'an Di Generasi Islam Tanah Jawa. Yogyakarta: Nurmahera, 2017.

Muhammad Yasser Arafat. Berta'aruf Dengan Tilawah Langgam Jawa, Makalah
Diskusi Public " Polemik Tilawah AlQur'an Langgam Jawa" Di IAIN Purwokerto, Jawa Tengah Pada Tanggal 21 Februari 2017., n.d.

-. "Polemik Tilawah Al-Qur'an Langgam Jawadi , Pada Tanggal ." IAIN Purwokerto, 2017.

—. "Tarekat Tilawatiyah: Melantunkan Al-Qur'an, Memakrifati Diri, Melakonkan.” program Magister Antropologi Budaya Fakultas Ilmu Budaya Universitas Gajah Mada, 2013.

Muhsin Salim. Ilmu Nagham Al-Qur'an Dan Belajar Membaca Al-Qur'an Dengan Lagu (Metode SBA TEOTIK). Jakarta: PT. Kebayoran Widya Ripta, 2004.

Nisaul. "Wawancara Dengan Santri Mukim," September 4, 2017.

Nur Kholis Setiawan. Al-Qur'an Kitab Sastra Terbesar. Yogyakarta: elSAQ Press, 2009.

Philip K. Hitti. Sejarah Ringkas Dunia Arab. Translated by Ushuludin Hutagalung \&O.D.P Sihombing. Yogyakarta: Pustaka Iqra, 2001.

Syahiron Syamsyudin. Islam Tradisi Dan Peradaban. Yogyakarta: SUKA-Press, 2012.

Ust. Bastomi. "Wawancara," September 9, 2017.

Wilfred Cantwell Smith. Kitab Suci AgamaAgama. Translated by Dedi Iswadi. Vol. II. Bandung: Teraju, 2005.

William A. Graham. Beyond The Written Wordm Oral Aspects of Scricture In The History of Religion. Cambridge, 1987. 